\title{
Growth patterns of Nothofagus pumilio trees along altitudinal gradients in Tierra del Fuego, Argentina
}

\author{
Guillermina Massaccesi · Fidel A. Roig • \\ Guillermo J. Martínez Pastur · Marcelo D. Barrera
}

Received: 17 April 2007/Revised: 24 September 2007/Accepted: 27 September 2007/Published online: 30 October 2007

(C) Springer-Verlag 2007

\begin{abstract}
The influence of ecological factors resulting from altitude on growth characteristics of Nothofagus pumilio was analyzed. $N$. pumilio forests grow in the southern Andes from near sea level to 600 m.a.s.l. Eight study sites were selected in the southwestern area of Tierra del Fuego, on north- and south-facing slopes, and distributed along an altitudinal gradient (200-600 m.a.s.l.). Growth cycles throughout time were identified. The correlation between climate and tree growth was determined. Tree diameter and height decreased whereas stand density increased towards tree-line. South-facing slopes showed higher values in common growth variability, probably because of stronger climatic controlling factors. Climategrowth correlation models revealed long-term temperature influences on growth variability, and showed variations among the different plots. Differences were detected in the spectral power component of the chronologies throughout the altitudinal profile. The series had a significant spectral peak at frequencies around 7 years, possibly related to mast
\end{abstract}

Communicated by Robert Guy.

G. Massaccesi ( $\square)$ · G. J. Martínez Pastur

Centro Austral de Investigaciones Científicas (CADIC)

CONICET, CC 92, Ushuaia, 9410 Tierra del Fuego, Argentina

e-mail: guim@gmx.net

F. A. Roig

Laboratorio de Dendrocronología e Historia Ambiental (IANIGLA) CONICET, CC 330, Mendoza, 5500 Mendoza, Argentina

\section{D. Barrera}

Laboratorio de Investigaciones de Sistemas Ecológicos y Ambientales (LISEA) UNLP, Diagonal 113, No 469 La Plata, 1900 Buenos Aires, Argentina seeding cycles. This signal became weaker as the altitude increased probably due to lower seed production. These results suggest a strong altitudinal component in growth variability of $N$. pumilio in Tierra del Fuego.

Keywords Southern Andes · Tree-line ·

Tree-ring analysis · Growth cycles · Nothofagus pumilio

\section{Introduction}

Tree rings are a valuable biological resource for studying ecologic and climatic processes at broad spatial and temporal scales. Dendroecological techniques are useful tools for exploring the relationships between environmental factors such as climatic variables and radial growth of trees (Fritts 1976; Schweingruber 1996; Copenheaver and Abrams 2003; Andreassen et al. 2006). Environmental driving forces of growth variation can be identified through the analysis of tree-ring series, assuming that trees located in the same environment or climatic region manifest parallel variations in growth.

In mountain regions, a well-known assumption is that as altitude increases, so do the stressing environmental conditions for living organisms (Larcher 1985). Air and soil temperatures diminish, affecting water availability, and increasing the probability of early frosts and the impact produced by snow (Barrera et al. 2000). Trees near the boundary of their ecological distribution along altitudinal gradients (such as upper treeline) are considered the most sensitive to environmental factors, yielding the strongest expected relationships between radial growth and climate (Kullman 1993; Cullen et al. 2001; Liu et al. 2001; Takahashi et al. 2003) Altitudinal influence on tree growth can be recorded in their tree rings (Splechtna et al. 2000; 
Buckley et al. 1997; Marchand 1980; Norton 1985). Nevertheless, studies on this subject are scarce, particularly for the southern Andean forests (Aravena et al. 2002; Schmelter 2000; Villalba et al. 1997). The objective of this study was to establish temporal and spatial growth patterns of Nothofagus pumilio (southern beech) in mountainous regions of Tierra del Fuego, Argentina, by analyzing how tree-ring development changes with respect to altitudinal gradients and slope aspect.

In the southern Andean forests, there are a gradual decrease of the size and changes in the shape of trees as the forests reaches its highest altitudes. The dominant height progressively decreases while the bases of the trunks tend to bend (Barrera et al. 2000; Eskuche, 1973). At the upper tree limit, the trees are prostrate and multi-stemmed, like the morphological types described for New Zealand by Norton and Schönenberger (1984).

\section{Materials and methods}

\section{Description of the study area}

Tierra del Fuego is the southernmost portion of South America and is extensively covered by forests (31\% of its surface) (Collado 2001). This area is also one of the closest forest systems to Antarctica. The Andean mountain range does not surpass 1,500 m.a.s.l., but it is sufficiently high to produce a sharp bioclimatic transition. The climate is subpolar, influenced by the Antarctic ice masses and cold oceanic currents. Mean annual temperatures at sea level are $5-6^{\circ} \mathrm{C}$, with minimums of $-14^{\circ} \mathrm{C}$ and frosts throughout the year (Tuhkanen et al. 1990). Air temperature decreases with altitude on an average of $0.55^{\circ} \mathrm{C} / 100 \mathrm{~m}$ (range between 0.43 and $0.70^{\circ} \mathrm{C}$ ), and precipitation increases with altitude from $550 \mathrm{~mm} /$ year at sea level (Ushuaia city) to $1,190 \mathrm{~mm} / \mathrm{year}$ at $535 \mathrm{~m}$.a.s.l (Martial Mountains) (Iturraspe et al. 1989).

Nothofagus (southern beech) is the main genus, which includes N. pumilio, N. antarctica (deciduous species), and $N$. betuloides (evergreen species). $N$. pumilio (lenga) is the most important tree species in the region, growing from sea level to ca. $650 \mathrm{~m}$, the altitudinal limit of the forest (Schmaltz 1991).

The study site was located in the forested southern part of Tierra del Fuego $\left(54^{\circ} 43^{\prime} \mathrm{S}, 68^{\circ} 00^{\prime} \mathrm{W}\right), 30 \mathrm{~km}$ northeast of Ushuaia city (Fig. 1). Sample sites included both northand south-facing slopes (these sites represent the major contrast of insolation in the Southern Hemisphere) and were established along altitudinal gradients from valleybottom to higher elevations of the montane beech forests immediately below the krummholtz zone (crippled stunted trees which growth on mechanically stressed sites). The sites (four in each aspect) were established in an altitudinal sequence at 220, 330, 460 and 550-590 m.a.s.1.

\section{Description of the stand structure}

Stand structure at each site was characterized by means of five sampling plots of variable radius using $K=6$ factor (an estimation of basal area) (Bitterlich 1984). Diameter at breast height $(\mathrm{DBH})$, dominant height and stand density were the variables quantified and compared.

Development of the tree-ring chronologies

Two perpendicular cores per tree were extracted at breast height from 15 to 17 trees per site using increment borers. All cores were from single-stemmed and straight bearing $N$. pumilio trees. Dominant trees were sampled in order to reduce the variation among the samples that could be attributed to growth competition among the trees (Piutti and Cescatti 1997). Cores were mounted on wood supports and mechanically polished using gradually finer grades of sandpaper. The dating process followed Stokes and Smiley (1968) method. The calendar age for each growth ring was established according to the Schulman's criteria (Schulman 1956) adopted for the Southern Hemisphere, which assigns each tree ring a calendar year that corresponds to the beginning of the growth for that year. Each tree-ring width was measured with a VELMEX measuring device with a precision of $\pm 0.001 \mathrm{~mm}$. Tree-ring measurements were recorded with the MEDIR program (International Tree-Ring Data Bank Program Library, Krusic et al. 1997) to develop the treering series, and were then subjected to further dendrochronological analysis to develop chronologies. First, possible errors in measuring and dating the tree rings were detected using the COFECHA program (Holmes 1983). Then, tree-ring chronologies were developed with the ARSTAN program (Cook and Holmes 1997), which combines standardized series with an estimation of the robust mean. Negative exponential function was applied alternatively with regression lines of negative slopes or horizontal lines to remove the individual growth signal component among tree samples. Then, each original series was divided by the corresponding standardization curve, resulting in a tree-ring index series for each sample within a study site. The individual tree-ring index series were then averaged on a year-by-year basis to compute a mean index chronology for each study site.

Ninety percent of the samples collected were successfully crossdated and were used to develop the final chronologies for each site. The series that could not be 


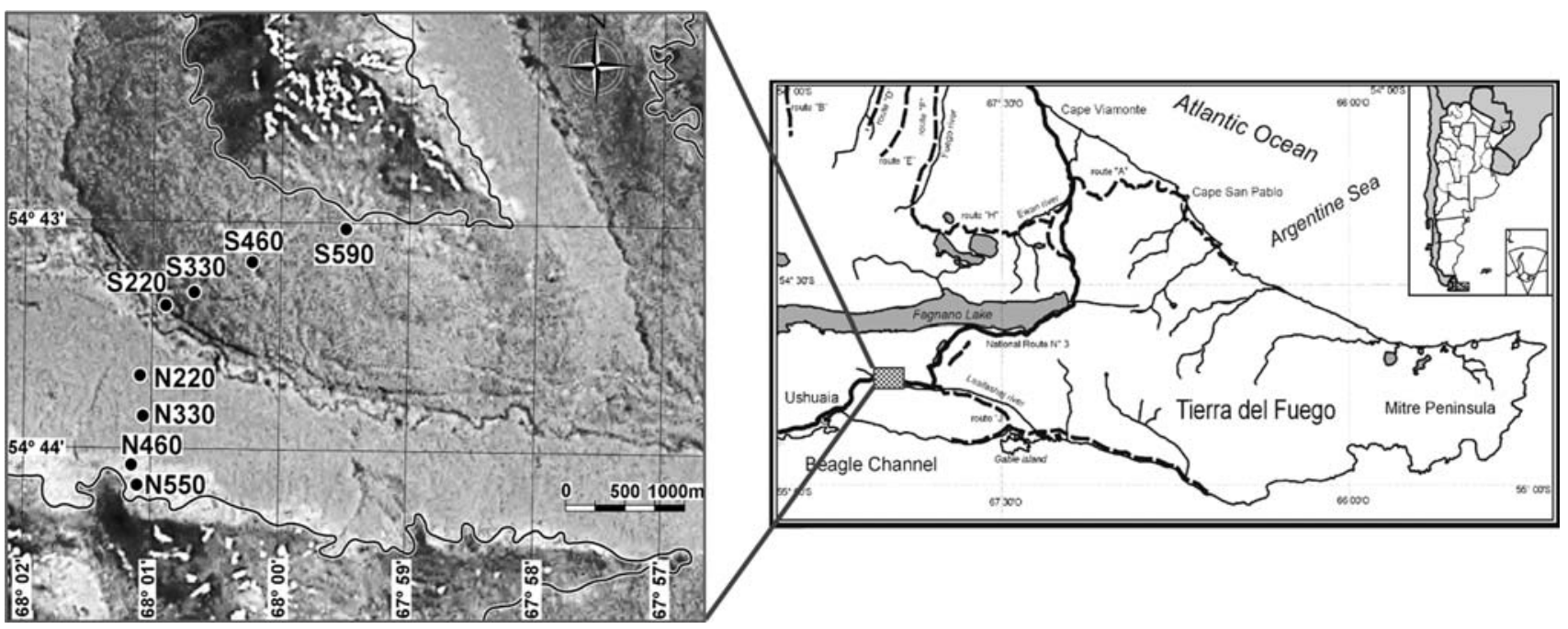

Fig. 1 Map and aerial view showing the locations of the study area and sampling sites (the drawing lines in the aerial image indicate the alpine timberline). See Table 1 for site identifications

crossdated resulted from samples that contained wide undistinguishable ring sectors or several types of wood trauma.

Spatial-temporal analysis of the tree-ring chronologies

Principal component analysis (PCA) was used to study relationships among tree-ring chronologies. A matrix was formed using eight 200-year long chronologies. Each chronology had a common time interval for the years 1803-2002 (199 years). A simple correlation analysis was also performed between the chronologies for north- and south- facing sites.

To identify the presence and significance of the growth rhythms and oscillations through time in the chronologies, the spectral technique defined by the Blackman-Tukey method (BT) was applied to the set of chronologies here developed (Jenkins and Watts 1968). In this technique, a series of ring-width indexes is considered as an infinite number of oscillations or cycles, described by an infinite number of wavelengths. Using spectral analysis, the frequency of each wavelength is estimated, and the results are expressed as a continuous wave distribution through the entire spectrum (Fritts 1976). We used the BTAUTO program version to generate the spectral density profiles (Cook, Personal communication). The BT spectrum was estimated from a number of autocorrelation lags equal to 100 , which approximately corresponds to $50 \%$ of the series length (period between 1803 and 2002). The 95\% confidence level of the BT spectrum is estimated from a red noise first-order Markov null continuum, which is based on the lag-1 autocorrelation of the time series.
Analysis of relationships between tree growth and climate

The influence of climatic factors on the annual growth of $N$. pumilio forests was investigated by developing correlations between the tree-ring chronologies and two climatic variables: (1) monthly precipitation records from meteorological stations of Ushuaia (Argentina) and Punta Arenas (Chile) cities and (2) the regional-scale land and sea-surface temperature (SST) record. These SST data that encompass our study area are organized in a $5^{\circ} \times 5^{\circ}$ grid of integrated land/sea temperatures (data provided by British Meteorological Office). Thus, the correlation analysis should document the seasonality and strength of the climate response of this species (Fritts 1976). A common time period of the years 1890-1990 was considered in these climate/tree-growth models for comparisons between climate data and tree-ring chronologies. Because previous climatic conditions can influence current growth, correlations were performed for each month of a 16-month period to encompass the Nothofagus growing season. A positive value in the model indicates above-average growth beyond the mean is related to a value above the mean of the climatic variable, and vice versa.

\section{Results}

Stand structure characteristics

Stand structural characteristics varied along the altitudinal gradient (Table 1). Tree height decreased significantly at higher elevations. On the south-facing 
Table 1 Site characteristics of the tree-ring chronologies

$D B H$ diameter at breast height

\begin{tabular}{llllllllr}
\hline $\begin{array}{l}\text { Code } \\
\text { site }\end{array}$ & Aspect & Latitude & Longitude & $\begin{array}{l}\text { Elevation } \\
(\mathrm{m} . \text { a.s.1. })\end{array}$ & $\begin{array}{l}\text { Slope } \\
\left(^{\circ}\right)\end{array}$ & $\begin{array}{l}\text { Tree height } \\
(\mathrm{m})\end{array}$ & $\begin{array}{l}\text { DBH } \\
(\mathrm{cm})\end{array}$ & $\begin{array}{l}\text { Density } \\
\text { (ind/ha })\end{array}$ \\
\hline S220 & South & $54^{\circ} 43^{\prime} 23.0^{\prime \prime} \mathrm{S}$ & $68^{\circ} 00^{\prime} 54.1^{\prime \prime} \mathrm{W}$ & 220 & 21 & 20 & 32.8 & 1,320 \\
S330 & South & $54^{\circ} 43^{\prime} 19.8^{\prime \prime} \mathrm{S}$ & $68^{\circ} 00^{\prime} 39.4^{\prime \prime} \mathrm{W}$ & 330 & 16 & 20.2 & 48.3 & 902 \\
S460 & South & $54^{\circ} 43^{\prime} 11.5^{\prime \prime} \mathrm{S}$ & $68^{\circ} 00^{\prime} 12.4^{\prime \prime} \mathrm{W}$ & 460 & 9 & 13.8 & 33.7 & 1,703 \\
S590 & South & $54^{\circ} 43^{\prime} 03.1^{\prime \prime} \mathrm{S}$ & $67^{\circ} 59^{\prime} 29.4^{\prime \prime} \mathrm{W}$ & 590 & 10 & 5.7 & 13 & 4,009 \\
$\mathrm{~N} 220$ & North & $54^{\circ} 43^{\prime} 41.0^{\prime \prime} \mathrm{S}$ & $68^{\circ} 01^{\prime} 04.0^{\prime \prime} \mathrm{W}$ & 220 & 25 & 24.5 & 63.1 & 206 \\
$\mathrm{~N} 330$ & North & $54^{\circ} 43^{\prime} 51.4^{\prime \prime} \mathrm{S}$ & $68^{\circ} 01^{\prime} 02.7^{\prime \prime} \mathrm{W}$ & 330 & 17 & 20.3 & 55.1 & 748 \\
$\mathrm{~N} 460$ & North & $54^{\circ} 44^{\prime} 03.7^{\prime \prime} \mathrm{S}$ & $68^{\circ} 01^{\prime} 7.64^{\prime \prime} \mathrm{W}$ & 460 & 18 & 14.1 & 46.7 & 607 \\
$\mathrm{~N} 550$ & North & $54^{\circ} 44^{\prime} 09.0^{\prime \prime} \mathrm{S}$ & $68^{\circ} 01^{\prime} 05.2^{\prime \prime} \mathrm{W}$ & 550 & 28 & 13.2 & 40.5 & 658 \\
\hline
\end{tabular}

slope, tree height decreased from $20 \mathrm{~m}$ on lower elevation sites to $6 \mathrm{~m}(F: 210.73 ; P<0.001)$. On the north-facing slope, tree heights varied from 25 to $13 \mathrm{~m}$ (F: 23.4; $P<0.001$ ). Tree diameter at breast height (DBH) was significantly smaller near the altitudinal limit (F: $17.93 ; P<0.001$ for the south-facing, and $F$ : 6.36 ; $P: 0.005$ for the north-facing slopes). Stand density was significantly higher at upper elevations on the southfacing slope $(F: 5.72 ; P<0.001)$ but it was not significant on the north-facing slope. There were no significant differences for any of the parameters studied when north- and south-facing slopes were compared with each other.

Tree-ring chronology characteristics

On both slopes, as altitude increased, the maximum age of chronologies decreased (Table 1). However, on sites at the lower elevation, the tree-ring records were shorter than expected, probably because a large proportion of stems were affected by decay and some former logging activity. The time interval covered by the chronologies varied between 200 and 300 years (Table 2, Fig. 2).
The mean ring-width value and its standard deviation decreased with increased altitude. The signal-to-noise ratio (SNR) increased with altitude on the south-facing slope. The opposite trend was observed for the north-facing slope. The mean correlation between trees (r-bt,) and the mean sensitivity (Table 2) slightly decreased with altitude. The common variance in growth, which is explained by the first eigenvector of a PCA (Table 2), showed a decrease with altitude.

Spatial relationships between chronologies

The correlation coefficients between the chronologies for north- and south-facing slopes diminished as the difference in altitude between individual sample sites increased (Fig. 3). The relative position of each chronology in relation to the first two axes of the principal component analysis is shown in Fig. 4. The first eigenvector explains $56 \%$ and the second eigenvector explains $14 \%$ of the total variance $(70 \%$ of the accumulated variance). The first principal component (PC1) does not discriminate sites. PC1 is associated with geographic variables because the sampling sites are within a small area and, therefore, under

Table 2 Statistics for the Nothofagus pumilio chronologies along an altitudinal gradient and opposite aspect over the entire period (A) and common interval (covered at least by 10 series) $(B)$

\begin{tabular}{llllllllrr}
\hline Site & $\begin{array}{l}\text { Period (trees/radii) } \\
\text { (A) }\end{array}$ & Years & MRW & Mean sensitivity & AC & $\begin{array}{l}\text { Common interval (trees/radii) } \\
\text { (B) }\end{array}$ & r-bt & SNR & Var. 1st ev. \\
\hline S220 & $1773-2002(15 / 28)$ & 230 & $1.68(0.95)$ & 0.373 & 0.555 & $1827-2002(7 / 12)$ & 0.412 & 4.91 & 50.64 \\
S330 & $1700-2002(15 / 29)$ & 303 & $1.30(0.66)$ & 0.334 & 0.602 & $1889-2002(14 / 23)$ & 0.439 & 10.95 & 49.45 \\
S460 & $1712-2002(14 / 32)$ & 291 & $1.02(0.41)$ & 0.221 & 0.634 & $1885-2002(13 / 23)$ & 0.351 & 7.03 & 40.34 \\
S590 & $1803-2002(16 / 34)$ & 200 & $1.73(0.33)$ & 0.31 & 0.553 & $1921-2001(16 / 31)$ & 0.403 & 10.80 & 44.92 \\
N220 & $1792-2002(17 / 31)$ & 211 & $1.73(0.89)$ & 0.317 & 0.56 & $1914-1993(16 / 26)$ & 0.535 & 18.38 & 56.65 \\
N330 & $1725-2002(15 / 29)$ & 278 & $0.94(0.49)$ & 0.286 & 0.486 & $1817-2002(13 / 21)$ & 0.403 & 8.78 & 45.18 \\
N460 & $1744-2002(14 / 25)$ & 259 & $1.15(0.50)$ & 0.245 & 0.539 & $1883-1994(13 / 18)$ & 0.342 & 6.74 & 39.77 \\
N550 & $1769-2002(15 / 26)$ & 234 & $1.29(0.55)$ & 0.207 & 0.624 & $1899-2002(13 / 19)$ & 0.318 & 6.07 & 38.37 \\
\hline
\end{tabular}

$M R W$ mean ring width in $\mathrm{mm} ; A C$ lag-one autocorrelation; r-bt: mean correlation between trees (\% Y variance); SNR signal to noise ratio; Var. $1 \mathrm{st}$ ev.: variance in first eigenvector in percentage, the standard deviation in parenthesis 
Fig. 2 Tree-ring index variations for Nothofagus pumilio standard chronologies along both South and North aspect altitudinal gradients in Tierra del Fuego. Arrows indicate the first narrowest tree rings. See Table 1 for the site identifications
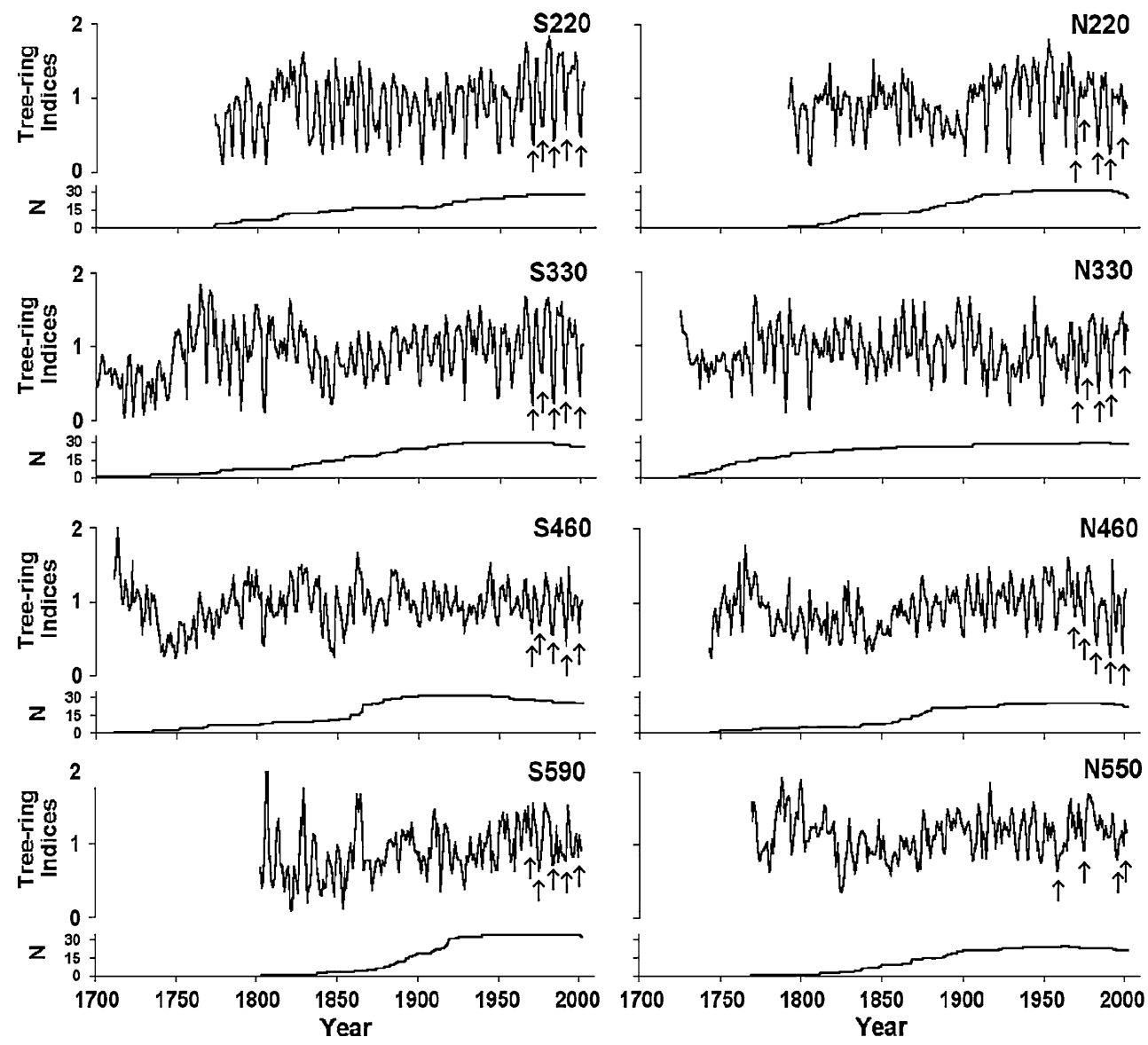

the influence of similar general climate controls. However, PC2 separates the chronologies into two groups: one group is comprised of the chronologies for sites located at higher altitudes (higher than 460 m.a.s.l.), and the other group is comprised of chronologies for sites located at the lower altitudes (lower than 330 m.a.s.l).

Influence of the climate on growth

Temperatures of the previous and current summers were positively correlated with growth for all of the chronologies (Fig. 5). The correlation between summer temperatures and growth for the chronologies for sites at higher altitudes (on both slope aspects) were stronger than those for sites located at lower elevations. There was a significant correlation between mean temperature for current November and December and growth for all chronologies. However, for the sites at the highest altitude on both aspects, there was a delay in the growth response. For these sites, growth during December and January are significantly correlated with temperature (Fig. 5). However, there was no significant correlation between growth and total monthly precipitation at any altitude or exposition. The stronger correlations between growth and temperature suggest that this variable (principally the summer temperature) is the main climatic factor affecting the radial growth of $N$. pumilio in the study area.

As shown previously, the relative position of chronologies due to altitude but not by aspect is more discriminant in terms of similarities regarding tree growth patterns and response to climate. For this reason the chronologies by altitudinal level were rebuilt (mixing south and north slopes) and their relationship with climate was recalculated. Figure 5 (right column) confirms that this model satisfactorily explains the dominant incidence of the altitudinal gradient on the growth response to climate.

Variations in growth characteristics

The BT spectra for all $N$. pumilio chronologies shows that a large component of the spectral power is concentrated at cycles of the high frequency domain (less than 10 years). Particularly strong is the significant spectral peak that appears at frequencies around 7 years $(P<0.05$; frequency of 0.145 cycles per year) (Fig. 6). This peak, which concentrates a large portion of the total variance of the 


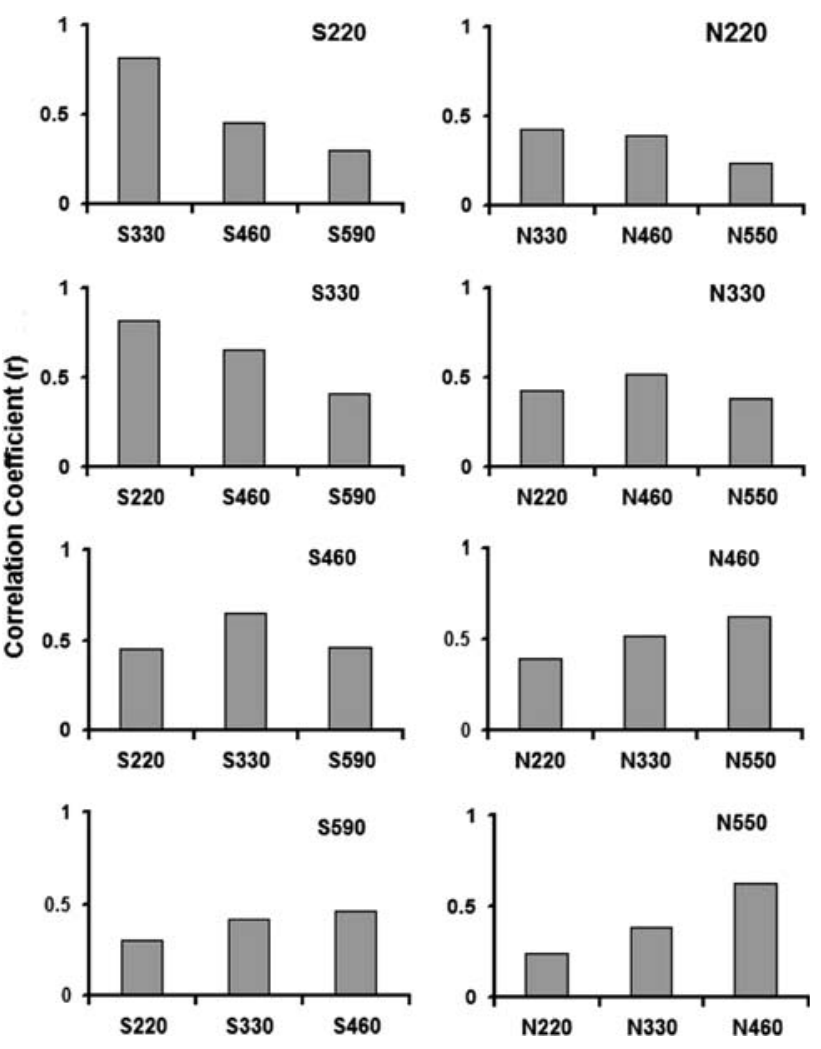

Fig. 3 Correlation coefficients among tree-ring chronologies along both South and North aspect altitudinal gradients in Tierra del Fuego. The correlation coefficients are all significant ( $P: 0.000$ in every case). See Table 1 for the site identifications

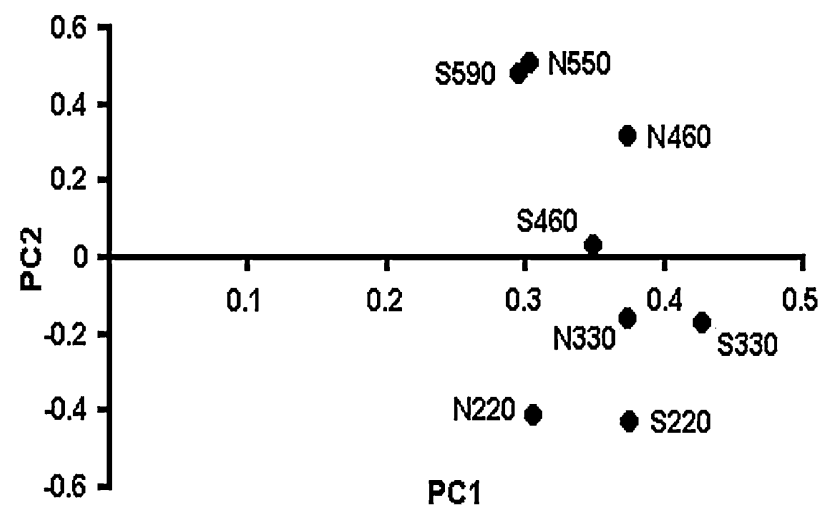

Fig. 4 Principal component analysis $(P C A)$ of the eight Nothofagus pumilio chronologies in Tierra del Fuego (common interval 18032002) (eigenvector 1 vs. eigenvector 2). See Table 1 for the site identifications

spectrum, shows a variance concentration according to altitude with a sequence of $18,7,4$ and $4.2 \%$ and of 10.5 , $12,6.5$ and $4 \%$ for south-facing and north-facing slopes, respectively. This 7-year oscillatory component is associated with the presence of a very narrow ring. As well, peaks located at frequencies between three to five years are also significant (at a 95\% confidence level), although they have a smaller incidence in the cumulated variance of the spectrum in comparison to the 7-year cycle.

As well as the comparisons between climate and chronologies arranged by altitudinal position, the BT method was applied to the set of chronologies established in an altitudinal sequence at 220, 330, 460 and 550-590 m.a.s.l. The new spectral density profiles showed identical spectral powers concentrated at the same cycles of the high frequency domain, confirming the dominant effect of altitude on tree growth patterns.

\section{Discussion and conclusion}

The interest in understanding the influence of physical variables on the development of plants in mountain areas is demonstrated by studies related to the effect of elevation on forest development (Holtmeier 2000; Turner and Tranquillini 1985; Tranquillini 1979). Nevertheless, this knowledge, supported by several studies in the Northern Hemisphere, is still fragmented and scarce for the Southern Hemisphere, particularly for the southern Andean forests (Cuevas 2003; Barrera et al. 2000; Troll 1973).

Structural characteristics of the forest such as height and diameter decrease while stand density increase towards the sites at higher altitudes (Barrera et al. 2000) In this study, $\mathrm{DBH}$ and age at lower sites on the south-facing aspect were decreased, but this may be the result of some harvesting that has modified the original forest structure (this site is near a road). Similar changes in structural characteristics were reported by Barrera et al. (2000) in Tierra del Fuego and by Norton (1985) in New Zealand. There were no obvious growth differences when comparing sites on the south- and north-facing slopes. Although, on the northfacing slope, the intensity of sunlight is greater than on the south-facing slope, a fact that favors the growth and developmental conditions of the forest. However, humidity is lower on the northern slope than on the southern slope, which would limit growth. As the altitude increases not only the structural characteristics of the forest vary, but also the tree growth forms. At the lowest sites the trees appeared erect, whereas at the tree line, the base of most trunks were curved possibly due to snow bending or soil creep and trees became multi-stemmed as influenced by the effect of wind and snow pressure (Barrera et al. 2000; Norton and Schönenberger 1984).

Tree-ring analysis is useful for understanding the ecological requirements and growth characteristics of mountain tree species. Studies of the New Zealand Nothofagus solandri forests have shown that there is a direct relationship between altitude and changes in some of the dendrochronological parameters, such as the mean sensitivity, signal-to-noise ratio, common variance, and first 


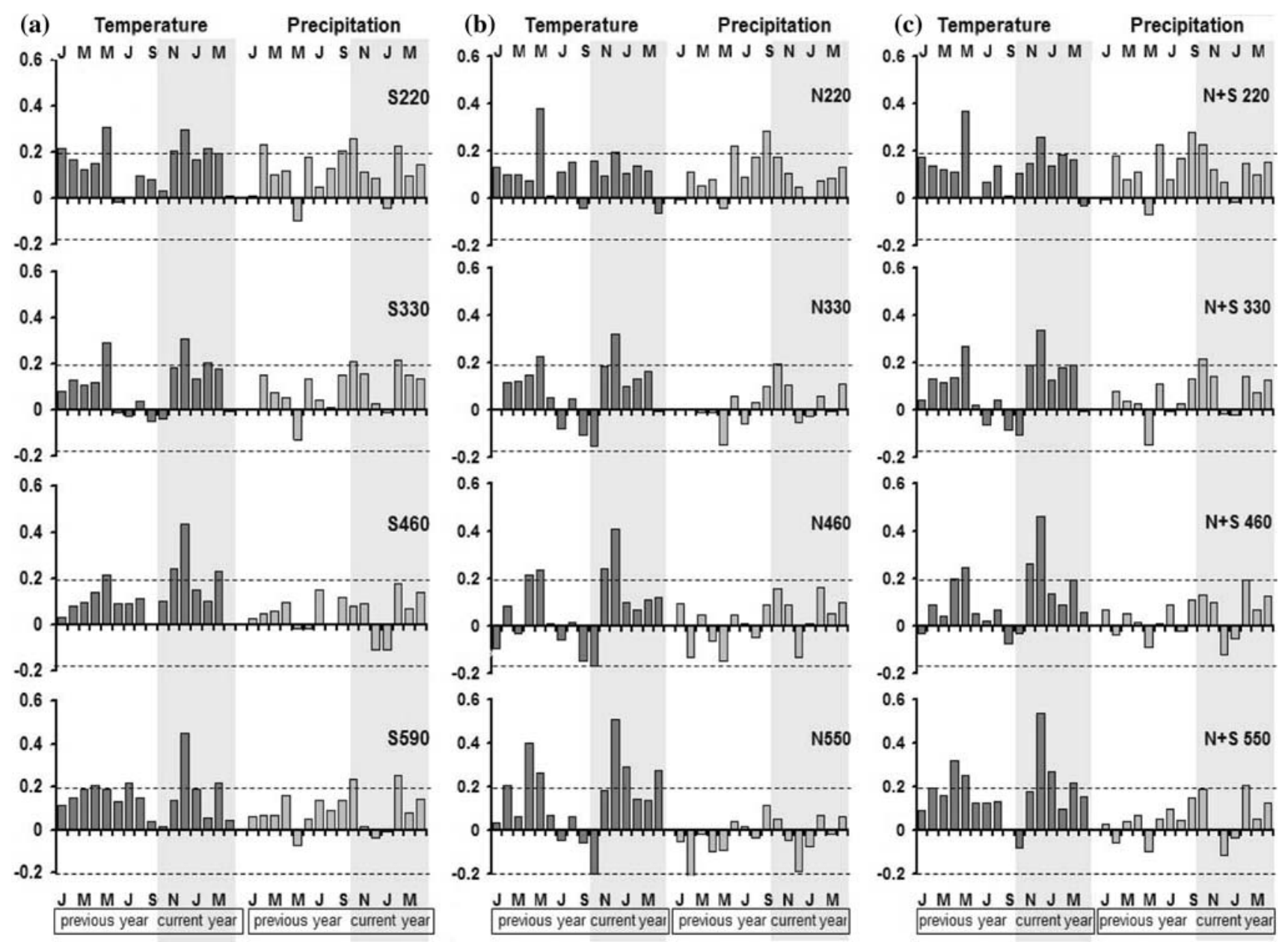

Fig. 5 Correlation coefficients between the eight Nothofagus pumilio chronologies and SST data (regional scale land and sea surface temperature) and monthly precipitation data from Ushuaia and Punta
Arenas (common interval 1890-1999). a South aspect, b North aspect and c Combined chronologies from South and North aspect. Dotted lines indicate $95 \%$ confidence intervals

The altitudinal gradients in Tierra del Fuego have a direct relationship to the type and strength of the treegrowth/climate relationship. In general, the radial growth of $N$. pumilio increased with increasing air temperatures, mainly during the summer months. Previous studies involving Nothofagus trees in southwest Tierra del Fuego and Isla de los Estados (D'Arrigo and Villalba 2000; Boninsegna et al. 1989), northern Patagonia (Schmelter 2000; Villalba et al. 1997) and New Zealand (Norton et al. 1989) also suggest this positive relationship between growth and temperature, but with some variations in strength relative to altitude and aspect. The relationships between tree growth and climate variations in Tierra del Fuego become stronger as the altitude increases, indicating that tree growth is most sensitive to climatic conditions at the highest altitudinal limits of the forest. Many other conifers and broadleaf species outside the Andes show this same pattern (Buckley et al. 1997; Marchand 1980). The radial growth of $N$. pumilio is more sensitive to variations 
Fig. 6 Blackman-Tuckey power spectra for the eight chronologies developed for southern and northern aspects in an altitudinal gradient in Tierra del Fuego (common interval 1803-2002). Dotted lines show the $95 \%$ confidence limit. Arrows show the 7-year peak. a South aspect, b North aspect and $\mathbf{c}$ Combined chronologies from South and North aspect
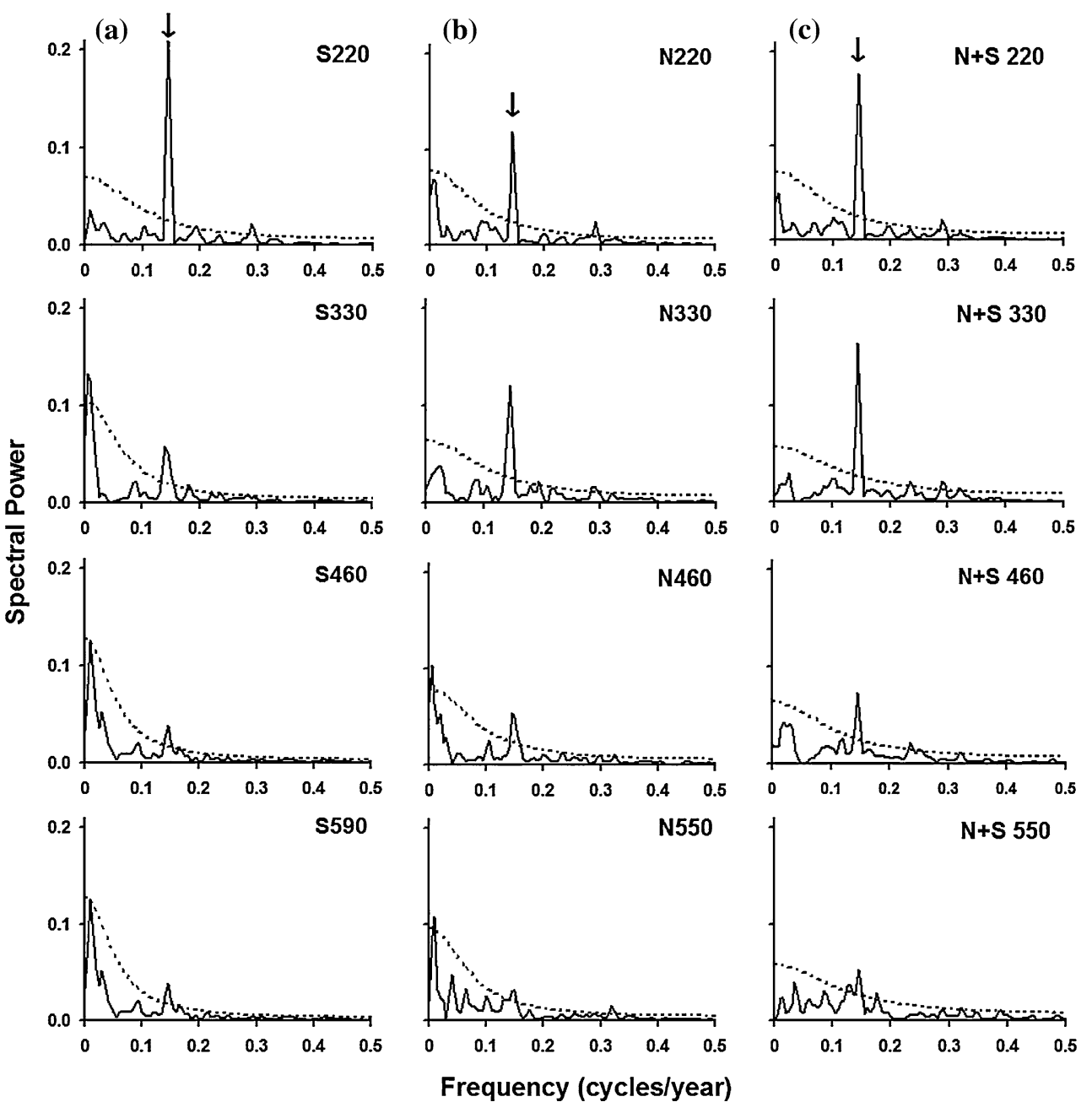

Frequency (cycles/year) in temperature in late spring and early summer. November and December mean temperatures are most strongly correlated with tree growth at lower sites, whereas, at highelevation sites, the months corresponding to increased tree growth vary with aspect (December for the south-facing slope and December and January for the north-facing slope). The difference among lower and higher sites may be related to the shorter growing season at the altitudinal forest limit (Barrera et al. 2000; Benecke and Havranek 1980; Roig et al. 2002; Rusch 1993; Tranquillini 1964).

Tree growth variability is reflected by a rich blend of oscillations at inter-annual to decadal frequencies that represents modulations by internal physiological rhythms and external environmental influences. However, the growth oscillations are related to the altitude. The Fuegian $N$. pumilio trees show a conspicuous growth cycle, which is represented by a very narrow growth ring produced approximately every 7 years. This growth particularity is useful in identifying pointer years to facilitate cross-dating. The 7-year cycle was first detected in the Nothofagus trees of Tierra del Fuego by Boninsegna et al. (1989) and Roig et al. (1996), and later identified by Aravena et al. (2002) in trees growing on Isla Navarino, south of Tierra del Fuego. As a general assumption, tree growth is modulated by environmental influences as well as by other rhythmic events typified by physiological characteristics of trees or population dynamics, such as mast seeding production or massive insect attacks, respectively. For example, a 7-year cycle has been detected in Larix decidua forests as a result of the periodic insect attacks (Schweingruber 1996). Although defoliating insects are known to attack N. pumilio in Patagonia (Veblen et al. 1996), there is scant information supporting the idea that massive increases in these insect populations occur in recurrent cycles. On the other hand, episodic mast seeding in $N$. pumilio might be considered a component responsible for the very narrow ring production. The scientific rationale for this cause-effect relationships lies in the fact that a peak in seed production would imply a higher energy investment in seed formation than in other functions like xylem production, which in turn would result in a narrow ring formation. Thus, reproductive and vegetative growth are usually negatively 
correlated (Kramer and Kozlowsky 1979). Negative correlations between reproduction and radial growth increment have been recorded in other species of Nothofagus such as $N$. truncata in New Zealand (Monks and Kelly 2006), and other genera such as Abies (Powell 1977), Dacrydium (Norton and Kelly 1988), Acer, Betula, Fagus, Picea, Pinus and Pseudotsuga (Kelly and Sork 2002).

In the $N$. pumilio forests of Seno Skyring, in the southern sector of continental Chile and $350 \mathrm{~km}$ from our study site, Schmidt et al. (1997) recorded a 20-year continuous lenga seed-production series, in which noticeable increases in seed production every 6-8 years were observed. These mast seeding episodes broadly agree with the 7-year periodicity observed in tree rings. Furthermore, in the Chilean side of Tierra del Fuego, Cuevas (2002) demonstrated that $N$. pumilio episodically regenerates in 78 year cycles, which coincide with years of maximum seed production.

On the other hand, it was noted that the 7-year cycle detected in the frequency spectra of the tree-ring chronologies was particularly strong at lower sites, while, this signal became weaker towards treeline. Cuevas (2002) observed that in years of greatest regeneration, the seedling density was higher at lower altitudes and lower at higher altitudes. The higher levels of seed production observed for $N$. pumilio at lower altitudes has also been verified for other tree species at similar altitudinal belts (Szeics and MacDonald 1995; Allen and Platt 1990; Manson 1974; Wardle 1981, 1970). Thus, the lower energy invested in fructification at high altitudes might lead to a weaker 7year cycle than at lower altitudes

In the chronologies of the eastern Tierra del Fuego (Argentinean side), the summers corresponding to narrower rings during the last 30 years were at 1983/1984, 1990/1991, 1999/2000, while the years of maximum seed production observed in the western Tierra del Fuego (Chilean side) were at 1982, 1988 and 1996, representing a 1-3 year delay of events between areas (Schmidt et al. 1997). The 7-year cycle in ring-width chronologies is similar to those in seed production and differential regeneration at different altitudes that have been observed in other regions of southern Argentina and Chile. Unfortunately, causes of this phenomenon are still poorly understood because of the lack of local long-term seed production datasets for this species or mast seeding evidence, preventing any direct comparison with our data. Furthermore, more specific studies on this topic are needed to explain certainly if there is a relationship among radial growth and seed production or mast seeding in N. pumilio in the southern Andes.

The present work demonstrates that the altitudinal gradients in Tierra del Fuego have a dominant influence on tree growth variability and on the strength of the relationship between tree growth and climate. The different radial growth patterns observed in the Tierra del Fuego $N$. pumilio forests in response to environmental variability along elevation gradients should be strongly considered in sampling strategies for further ecological and climatic interpretations.

Acknowledgments The authors thank Luis Pinedo and Vanessa Lencinas for their help during field works and Alberto Ripalta and Rafael Bottero for their technical support. This research was made possible by funding from CONICET (Grant No PID02885, Res. 793) and ANPCyT (Grant No PICTR2002-00067).

\section{References}

Allen RB, Platt KH (1990) Annual seed fall variation in Nothofagus solandri (Fagaceae) Canterbury, New Zealand. Oikos 57:199_ 206

Andreassen K, Solberg S, Tveito OE, Lystad SL (2006) Regional differences in climatic responses of Norway spruce (Picea abies L. Karst) growth in Norway. For Ecol Manage 222:211-221

Aravena JC, Lara A, Wolodarsky-Franke A, Villalba R, Cuq E (2002) Tree-ring growth patterns and temperature reconstruction from Nothofagus pumilio (Fagaceae) forests at the upper tree-line of southern Chilean Patagonia. Rev Chil Hist Nat 75:61-376

Barrera MD, Frangi J, Richter L, Perdomo M, Pinedo L (2000) Structural and functional changes in Nothofagus pumilio forests along an altitudinal gradient in Tierra del Fuego, Argentina. J Veg Sci 11:179-188

Benecke U, Havraneck WM (1980) Phenological growth characteristics with increasing altitudes, Craigieburn range, New Zealand. For Service Tech Pap 70:155-174

Bitterlich W (1984) The relascope idea: relative measurements in forestry. Commonw. Agric. Bur. Farnham Royal, England

Boninsegna JA, Keegan J, Jacoby GC, D’Arrigo R, Holmes RL (1989) Dendrochronological studies in Tierra del Fuego, Argentina. Quat South Am Antarc Pen 7:305-326

Buckley BM, Cook ER, Peterson MJ, Barbetti M (1997) A changing temperature response with elevation for Lagostrobos franklinii in Tasmania, Australia. Clim Change 36:477-498

Collado L (2001) Los bosques de Tierra del Fuego: Análisis de su estratificación mediante imágenes satelitales para el inventario forestal de la provincia. Multequina 10:1-15

Cook E, Holmes RL (1997) ARSTAN: chronology development. In: Grissino-Mayer D, Holmes RL, Fritts HC (eds) The international Tree-Ring Data Bank Program Library Version 2.1 User's Manual. Laboratory of Tree-Ring Research, The University of California, Tucson, pp 75-87

Copenheaver CA, Abrams MD (2003) Dendroecology in young stands: case studies from jack pine in northern lower Michigan. For Ecol Manage 182:247-254

Cuevas JG (2002) Episodic regeneration at the Nothofagus pumilio alpine timberline in Tierra del Fuego, Chile. J Ecol 90:52-60

Cuevas JC (2003) Gap regeneration in relation to forest structure and implications for southern beech forest dynamics. Can J For Res 33:1915-1922

Cullen LE, Palmer JG, Duncan RP, Stewart GH (2001) Climate change and tree-ring relationships of Nothofagus treeline forests. Can J For Res 31:1981-1991

D'Arrigo RD, Villalba R (2000) Review of dendroclimatic research at high latitudes in South America: indicators of atmosphere-ocean climate variability. In: Roig FA (ed) Dendrochronology in Latin America EDIUNC, Mendoza, pp 271-282 
Eskuche U (1973) Estudios fitosociológicos en el norte de la Patagonia. I. Investigación de algunos factores de ambientes en comunidades de bosque y chaparral. Phytocoen 1:64-113

Fritts HC (1976) Tree rings and climate. Academic, London

Holmes RL (1983) Computer-assisted quality control in tree-ring dating and measurement. Tree Ring Bull 43:69-75

Holtmeier FK (2000) Die Höhengrenze der Gebirgswälder. Arbeiten aus dem Institut für Landschaftsökologie 8. Münster, Germany

Iturraspe R, Sottini R, Schroeder C, Escobar J (1989) Hidrología y variables climáticas del Territorio de Tierra del Fuego: Información básica. (CONICET-CADIC). Contribución 7. Ushuaia, Argentina

Jenkins GM, Watts DG (1968) Spectral analysis and its applications. Holden-Day. Oakland

Kahle H-P (1994) Modellierung der Zusammenhänge zwischen der Variation von klimatischen Elementen des Wasswehaushalts und dem Radialzuwachs vos Fichen [Picea abies (L.) Karst.] aus Hochlagen des Südschwarzwalds. Ph.D. Thesis. University of Freiburg, Germany

Kelly D, Sork VL (2002) Mast seeding in perennial plants: why, how, where? Ann Rev Ecol Syst 33:427-447

Kramer P, Kozlowski T (1979) Physiology of woody plants. Academic, New York

Krusic PJ, Holmes RL, King JC (1997) MEDIR Version 1.13 measurement program. In: Grissino-Mayer D, Holmes RL, Fritts HC (eds) The International Tree-Ring Data Bank Program Library Version 2.1 User's Manual. Laboratory of Tree-Ring Research. The University of California, Tucson, pp 18-20

Kullman L (1993) Tree limit dynamic of Betula pubescens ssp tortuosa in relation to climatic variability: evidence from central Sweden. J Veg Sci 4:765-772

Larcher W (1985) Winter stress in high mountains. In: Turner H and Tranquillini W (eds) Establishment and tending of subalpine forests: research and management. Proceedings of 3rd IUFRO Workshop, 1984. Eidgenössische Anstalt für das forstliche Versuchswesen, Berichte 270, pp 11-19

Liu H, Tang Z, Dai J, Tang Y, Cui H (2001) Larch timberline and its development in North China. Mt Res Dev 22:359-367

Mäkinen H, Nöjd P, Kahale H-P, Neuman U, Tveite B, Mielikäinen K, Röhle H, Spieker H (2002) Radial growth variation of Norway spruce [Picea abies (L.) Karst.] across latitudinal and altitudinal gradients in central and northern Europe. For Ecol Manage 171:243-259

Manson BR (1974) The life history of silver beech (Nothofagus menziezii). Proc NZ Ecol Soc 21:27-31

Marchand PJ (1980) Causes of coniferous timberline in the northern Appalachian Mountains. In: Benecke U, Davis MR (eds) Mountain Environments and Subalpine Tree Growth. Forest Research Institute Technical Paper 70. New Zealand Forest Service, Wellington, pp 231-246

Monks A, Kelly D (2006) Testing the resource-matching hypothesis in the mast seeding tree Nothofagus truncata (Fagaceae). Austral Ecol 31:366-375

Norton DA (1985) A dendrochronological study of Nothofagus solandri tree growth along an elevational gradient, South Island, New Zealand. In: Turner H, Tranquillini W (eds) Establishment and tending of subalpine forests: research and management. Proceedings of 3rd IUFRO Workshop, 1984. Eidgenössische Anstalt für das forstliche Versuchswesen, Berichte, pp 159-171

Norton DA, Schönenberger W (1984) The growth forms and ecology of Nothofagus solandri at the alpine timberline, Craigieburn range, New Zealand. Arc Alp Res 16:361-370

Norton DA, Kelly D (1988) Mast seeding over 33 years by Dacrydium cupressinum Lamp. (rimu) (Podocarpaceae) in New Zealand: the importance of economies of scale. Funct Ecol 2:399-408
Norton DA, Briffa KR, Salinger MJ (1989) Reconstruction of New Zealand summer temperatures to $1730 \mathrm{AD}$ using dendroclimatic techniques. Int J Climatol 9:633-644

Piutti E, Cescatti A (1997) A quantitative analysis of the interactions between climatic response and intraspecific competition in European beech. Can J For Res 27:277-284

Powell G (1977) Biennial strobilus production in balsam fir: a review of its morphogenesis and a discussion of its apparent physiological basis. Can J For Res 7:547-555

Roig FA, Roig C, Rabassa J, Boninsegna JA (1996) Fuegian floating tree-ring chronology from subfossil Nothofagus wood. The Holocene 6:469-476

Roig FA, Martinez Pastur G, Moyano V, Pinedo L, Lencinas MV (2002) Cambial activity, phenology and climate in Nothofagus pumilio forests of Tierra del Fuego, Argentina. In: Proceedings of the international conference of dendrochronology, Canada, pp 22-27

Rusch VE (1993) Altitudinal variation in the phenology of Nothofagus pumilio in Argentina. Rev Chil Hist Nat 66:131-141

Savva Y, Oleksyn J, Reich PB, Tjoelker MG, Vaganov EA, Modrzynski J (2006) Interannual growth response of Norway spruce to climate along an altitudinal gradient in the Tatra Mountains, Poland. Trees 20:735-746

Schmaltz J (1991) Deciduous forests of southern South America. In: Röhrig E, Ulrich B (eds) Temperate deciduous forests. Ecosystems of the World 7. Elsevier, Amsterdam, pp 557-578

Schmelter A (2000) Climatic response and growth trends of Nothofagus pumilio along altitudinal gradients from arid to humid sites in northern Patagonia. In: Roig FA (ed) Dendrocronología en América Latina. EDIUNC, Mendoza, pp 193 215

Schmidt H, Caldentey J, Peña K (1997) Seguimiento forestal y ambiental del uso de los bosques de lenga. XII Región. Informe 1997. Universidad Nacional de Chile. Facultad de Ciencias Agrarias y Forestales. CONAF. Intendencia de la XII Región Magallanes y Antártida Chilena. Santiago, Chile

Schulman E (1956) Dendroclimatic change in semiarid America. University of Arizona Press, Tucson

Schweingruber FH (1996) Tree rings and environment. Dendroecology. Haupt Publish, Bern

Splechtna B, Dobry J, Klinka K (2000) Tree-ring characteristics of subalpine fir (Abies lasiocarpa (Hook.) Nutt.) in relation to elevation and climatic fluctuations. Ann For Sci 57:89-100

Stokes MA, Smiley TL (1968) An introduction to tree-ring dating. University of Chicago Press, Chicago

Szeics JM, Mac Donald GM (1995) Recent white spruce dynamics at the subarctic alpine treeline of northwestern Canada. J Ecol $83: 873-885$

Takahashi K, Azuma H, Yasue K (2003) Effects of climate on the radial growth of tree species in the upper and lower distribution limits of an altitudinal ecotone on Mount Norikura, central Japan. Ecol Res 18:549-558

Tardif J, Bergeron Y (1997) Comparative dendroclimatological analysis of two black ash and two white cedar population from contrasting sites in the Lake Duparquet region, northwestern Quebec. Can J For Res 27:108-116

Tranquillini W (1964) The physiology of plants at high altitudes. Annu Rev Plant Physiol 15:345-362

Tranquillini W (1979) Physiological ecology of the alpine timberline. Ecological studies. Springer, Berlin

Troll C (1973) The upper timberlines in different climatic zones. Arct Alp Res 5:3-18

Tuhkanen S, Kuokka I, Hyvonen J, Stenroos S, Niemela J (1990) Tierra del Fuego as a target for biogeographical research in the past and present. Anales del Instituto de la Patagonia (Serie Ciencias Naturales) 19:5-63 
Turner H, Tranquillini W (1985) Establishment and tending of subalpine forests: research and management. In: Proceedings of the 3rd IUFRO Workshop, 1984. Eidgenössische Anstalt für das forstliche Versuchswesen, Berichte 270

Veblen TT, Kitzberger T, Burns BR, Robertus AJ (1996) Perturbaciones y dinámica de regeneración en bosques andinos del sur de Chile y Argentina. In: Armesto J, Villagrán C, Kalin M (eds) Ecología de los bosques nativos de Chile. Editorial Universitaria, Santiago, pp 169-198
Villalba R, Boninsegna JA, Veblen TT, Schmelter A, Rubulis S (1997) Recent trends in tree-ring records from high elevation sites in the Andes of northern Patagonia. Clim Change 36:425454

Wardle J (1970) Ecology of Nothofagus solandri. N Z J Bot 8:494646

Wardle P (1981) Is the alpine timberline set by physiological tolerance, reproductive capacities or biological interactions? Proc Ecol Soc Aust 11:53-66 